\title{
Can Conservatism Make Women More Vulnerable to Violence?
}

Comparative Political Studies 2022, Vol. 55(I) I22-153

(C) The Author(s) 2021

\section{(c) (i) \$}

Article reuse guidelines: sagepub.com/journals-permissions DOI: 10.1 I77/00104|40211024313 journals.sagepub.com/home/cps

\section{(3)SAGE}

\section{Victor Araújo' $\odot$ and Malu A. C. Gatto ${ }^{2}$}

\begin{abstract}
Violence against women (VAW) affects at least $35 \%$ of women worldwide. The need to combat VAW is seemingly noncontroversial: As existing work shows, ideology does not explain governments' propensity to adopt antiVAW legislation. Yet, effectively implementing anti-VAW legislation requires complex policy frameworks at odds with conservative values. Voters' preferences can meaningfully influence policy outputs, so can electoral conservatism make women more vulnerable to violence? Employing data from 5570 Brazilian municipalities, we find that conservatism in the electorate is associated with the adoption of fewer anti-VAW policies. With data from a nationally representative survey of Brazilian respondents $(N=2086)$, we then show that conservative voters are less likely to prioritize the need for tackling VAW. That is, the adoption of fewer anti-VAW policies in conservative municipalities reflects conservative voters' policy preferences. Critically, our results suggest that in contexts where the electorate holds conservative preferences, policy responsiveness may incur costs to women's lives.
\end{abstract}

\section{Keywords}

political representation, ideology, violence against women, policy design, Brazil

\footnotetext{
'University of Zurich, Zurich, Switzerland

${ }^{2}$ University College London, London, UK

\section{Corresponding Author:}

Malu A. C. Gatto, Institute of the Americas, University College London, 5 I Gordon Square, London WCIH OPN, UK.

Email:m.gatto@ucl.ac.uk
} 


\section{Introduction}

The World Health Organization estimates that $35 \%$ of women worldwide have been subjected to intimate-partner violence or sexual violence by a nonpartner. The prevalence of intimate-partner violence is particularly high in developing countries (García-Moreno et al., 2013). In Brazil, it is estimated that one woman was affected by violence every 4 minutes in 2017 and an average of 13 women was murdered every day (Cerqueira et al., 2019).

These numbers are alarming and the need to combat violence against women (VAW) is seemingly noncontroversial. Unlike demands related to women's sexual and reproductive rights (Bentancur \& Rocha-Carpiuc, 2020), tackling VAW is not in inherent opposition to conservative or religious values (Htun \& Weldon, 2010; Htun \& Piscopo, 2014). In fact, efforts to protect women seem to be in alignment with traditional, paternalistic gender roles and views of women as fragile (Lodders \& Weldon, 2019). The non-dogmatic nature of VAW partly explains the rapid spread of anti-VAW policies (Beer, 2019), and legislation on domestic violence is now present in at least 155 countries (World Bank, 2020). As cross-national and within-country studies show, ideology does not explain governments' propensity to adopt anti-VAW legislation (e.g., Beer, 2017; Htun \& Weldon, 2012). In other words, conservative politicians do not seem to be less supportive of combating VAW than their more progressive counterparts.

While ideology may not impact support for anti-VAW legislation per se, it may shape actors' attitudes towards the policy frameworks necessary for the implementation of legislation. For example, as an emerging literature shows, once legislation is adopted, conservative groups with ties to state actors may work to undermine policies perceived to threaten the maintenance of family structures (Neumann, 2018; O'Brien \& Walsh, 2020).

There is still much that we do not know about the relationship between conservatism and anti-VAW policies, however: Although the literature has extensively covered the ways in which women's mobilization, international organizations, and transnational diffusion have prompted legal transformations on gender-based violence around the world, identifying the factors that curb progress on anti-VAW has remained a less explored line of work (O'Brien \& Walsh, 2020, p. 114). In this article, we make further strides in this direction by assessing whether and how voters' conservative preferences impact the adoption of policy instruments to tackle VAW in Brazil. Is so doing, we also respond to recent calls to understand the role of ideology in the postreform stage of the policy process (Bentancur \& Rocha-Carpiuc, 2020).

A key tenet of representative democracy is the notion that public policy reflects voters' interests and preferences (Przeworski et al., 1999). As a large body of work shows, the electorate shapes the actions of policymakers in meaningful ways (e.g., Ezrow et al., 2011; Lax \& Phillips, 2012). Voters that 
share ideological principles also tend to share policy preferences (Luna \& Zechmeister, 2005), so it is likely that conservative voters' attitudes towards tackling VAW are different from those of their progressive counterparts. In turn, effectively enacting anti-VAW legislation requires the implementation of complex policy frameworks (Tavares et al., 2019). If the political will of politicians to enact these policy infrastructures is tied to the preferences of their constituents, then it is possible that conservative voters' opposition to particular types of policy instruments (O'Brien \& Walsh, 2020), unwillingness to fund anti-VAW initiatives (Macaulay, 2010), and/or non-prioritization of VAW as a policy area (Page \& Shapiro, 1983) could have dire consequences to governments' efforts to eradicate gender-based violence.

Understanding whether voters' preferences can contribute to the weakening of anti-VAW provisions is an urgent exercise: Electoral conservatism is rising around the world (e.g., Biroli \& Caminotti, 2020; Kováts, 2018), so assessing whether it could pose threats to a non-dogmatic policy area is a hard test of ongoing concerns about the future of women's rights.

We investigate the relationship between voters' preferences and public policy outcomes with a two-step analysis. First, we examine whether electoral conservatism impacts the adoption of policy instruments to tackle VAW in Brazilian municipalities. When the Maria da Penha Law on Domestic and Family Violence (Federal Law 11.340) was approved in Brazil in 2006, it recognized domestic violence as gendered, typified different forms of violence, and identified a number of justice and protection mechanisms specifically targeted at tackling VAW. However, although the law applies nationally, the decision to select which and how many policy instruments to adopt (if any) remains under the authority of municipalities. As a result, there is wide variation in the uptake of these instruments across the country. Combining data from the Brazilian Institute of Geography and Statistics (IBGE) on the presence and number of policy instruments in each municipality with data on constituencies' "electorally revealed conservatism" developed by Power and Rodrigues-Silveira (2019), we assess whether municipalities with conservative electorates are less prone to adopting policy instruments to combat VAW $(N=5570)$.

Employing novel survey data from a nationally representative sample of Brazilian respondents $(N=2086)$, we then investigate whether holding conservative preferences shapes voters' attitudes towards VAW and the need to adopt further legislation to tackle it. This approach allows us to not only assess the association between constituencies' ideology and policy adoption but also to examine whether it is indeed voters' policy preferences that likely yield aggregate-level observed outcomes. In other words, by conducting analyses at the municipal and individual levels, we evaluate whether policy is responsive to voters (Lax \& Phillips, 2012). 
Aligned with current preoccupations about the potential threat of conservatism to women's rights, we find that municipalities with more conservative electorates adopt fewer policy instruments to tackle VAW - a result that remains significant across model specifications and after controlling for several municipal-level variants, including rates of femicide, bureaucratic capacity, and mayors' gender and conservative ideology. More specifically, we find that the negative impact of electoral conservatism on protection policies is stronger than its impact on justice policies, suggesting that preferences for policy responses to VAW are ideologically diverse. In complementary analyses, we also show that electorally conservative municipalities are not less likely to adopt policies in other areas, so weaker anti-VAW policy frameworks in more conservative municipalities do not seem to be a reflection of conservatives' general concerns about government spending.

Consistent with our municipal-level results, our individual-level analyses show that conservative respondents are more likely to deem existing laws sufficient to protect women and more prone to believing that press coverage of gender-based violence is exaggerated. These findings indicate that the lower presence of policy instruments in conservative municipalities emerges from conservative voters' non-prioritization of VAW as a problem that should be tackled by the government. Critically, our results suggest that in contexts where the electorate holds conservative preferences, congruous democratic representation may impose risks to women's lives. These findings have implications for the academic literature on political representation and ongoing debates about the potential consequences of the rise of conservatism for women's rights.

\section{Conservative Representation: A Threat to Women's Rights?}

Estimating the impact of actors' ideological identities on their policy preferences is not always clear-cut. The first challenge that arises is conceptual. "Conservatives" encompass actors from a broad range of parties and priorities, so the definitions and measurements of the concept vary widely ${ }^{1}$. Nonetheless, scholars tend to characterize "conservatives" as those who fall between the "center" and "right" placements of the ideological scale, which tend to be associated with preferences for preserving socio-cultural-and, often, religious - traditions, including patriarchal gender hierarchies and the centrality of hetero-normative family structures (Luna \& Kaltwasser, 2014; O’Brien, 2018).

Perhaps related to inconsistencies in definitions and measurements of ideology, particularly across countries (Beer, 2017), a second challenge arises: Establishing a clear association between ideological preferences and women's rights (Celis \& Childs, 2018). On the one hand, as a large body of literature 
shows, conservative politicians and parties tend to have fewer connections to women's civil society organizations and other progressive movements (e.g., Beckwith, 2000; Medie \& Walsh, 2019; Weldon et al., 2011) and are, as a consequence, less likely to incorporate their demands into their policy agendas (e.g., Beckwith \& Cowell-Meyers, 2007; Blofield et al., 2017; Caul, 2001).

On the other hand, as O'Brien (2018) describes: "There is mounting skepticism about the predictive power of ideology" (p. 27) in explaining preferences on women's rights and gender equality. Motivated by institutional and electoral incentives, conservative parties increasingly recruit women candidates and employ gendered perspectives into their rhetoric and platforms (e.g., Bryson \& Heppell, 2010; Celis \& Childs, 2012; Celis \& Erzeel, 2015).

In particular, ideology seems to be a weak predictor of politicians' behavior towards combating VAW, a non-dogmatic policy area. For example, in their cross-national study of 70 countries, Htun and Weldon (2012) find governments' dominant ideology to be insignificant to the adoption of anti-VAW legislation. In cross-national studies with different sets of countries, Weldon (2002b) and Mazur (2002) also show that the political ideology of the government in power is not a crucial factor prompting or preventing the adoption of VAW-related legislation. Beer (2017) finds similar results in her study of Mexican states. As she conveys, while bills tend to be initiated by left-wing feminist legislators, the strength of the left parties in state legislators is not associated with the level of comprehensiveness or implementation of VAW laws. In sum, existing analyses suggest that the ideology of politicians is not a determinant factor of support for anti-VAW legislation.

But to effectively tackle VAW, legislation has to be supported by on-theground targeted instruments of protection, prevention, and justice. Since gender-based violence can have long-standing physical, psychological, and economic impacts on women, their children, and other family members, policy responses also have to be multi-faceted. To prevent re-victimization, experts recommend that policy frameworks be comprehensive and provide women with safe spaces and efficient protocols to register offences; protection for them and their dependents; specialized medical and psychological support; and targeted judicial institutions (García-Moreno et al., 2013; Hayes, 2007; Hughes et al., 2016). For example, helplines, women's police stations, dedicated shelters, special courts, and legal representation are some types of instruments that can help bridge the "implementation gap between law and practice"(Tavares et al., 2019).

Some of the policy instruments advocated by international organizations and recommended by domestic laws may challenge conservative and religious preferences. VAW is overwhelmingly perpetrated by survivors' partners or former partners (Hughes et al., 2016), so tackling gender-based violence requires interventions in the domestic sphere, a space traditionally deemed as private (Neumann, 2018). But the maintenance of family units is a core 
principle of many conservatives and religious actors (Luna \& Kaltwasser, 2014). So, while conservatives may support policies that promote reconciliation and mediation between survivors and their perpetrators, they may strongly oppose "anti-family" mechanisms, such as protective measures (Neumann, 2018; O’Brien \& Walsh, 2020).

Conservatives may also be less willing to make the necessary budgetary commitments to tackle VAW. As Beer (2017) argues, adopting anti-VAW legislation is a "low cost way to appease to the feminist movement" (p. 515), but instituting instruments to effectively implement such legislation is not. In fact, as Tavares et al. (2019) detail, the allocation of government budget to fund targeted policy instruments is fundamental to ensure the successful implementation of anti-VAW legislation. Yet, conservative actors' willingness to support policies of women's rights may wane when such interventions require government spending (Macaulay, 2010).

Finally, the nonadoption of anti-VAW policy instruments may not necessarily result from attitudes towards public spending: Policy problems are not equally salient to voters (Jones \& Baumgartner, 2005) and ideology may impact the extent of voters' attention to a particular issue. So, even if conservatives give some emphasis to women's issues, they may still fall behind progressives in prioritizing these themes (Childs et al., 2010; O'Brien, 2018). Crucially, conservative actors' appropriation of gendered agendas may be rhetorical and not translate into strong policy preferences and action (Akkerman, 2015; Bryson \& Heppell, 2010). That is, if VAW is not a salient issue among conservatives, the nonadoption of policy instruments to tackle it may result not from a normative opposition to the issue, but from its nonprioritization on the policy agenda (Jones \& Baumgartner, 2005; Page \& Shapiro, 1983).

Crucially, conservatives' opposition to some type of policies, their lack of willingness to fund anti-VAW instruments, and/or their non-prioritization of this policy area may ultimately have consequences to anti-VAW policy frameworks. As the literature on elite-mass congruence shows, it is not only the ideology of politicians that shapes policymaking: Voters' preferences also matter (Erikson et al., 1993). In the context of the growing popularity of conservatism in the electorate, understanding whether the electorates' ideological composition can impact the adoption of policy instruments to tackle VAW is thus an important task.

\section{Electoral Conservatism and Anti-VAW Policies}

At the core of liberal representative democracy is the "pact" that citizens' preferences are to be translated into policies on-the-ground (Dahl, 1989). Behind this notion is the idea that, through free and fair elections, voters can both signal their policy priorities by selecting certain campaign platforms over 
others, as well as sanction incumbents who fail to enact their interests (Adsera et al., 2003; Huber \& Powell, 1994; Przeworski et al., 1999). Studies employing public opinion surveys have shown that while policymakers tend to have stronger and more consistent ideological convictions than citizens, partisans still tend to share core ideological principles (e.g., Luna \& Zechmeister, 2005). Crucially, as studies of different countries and contexts have shown, voters' preferences can shape different types of policy output - including party manifestos, politicians' public statements, bill sponsorship, legislators' behavior on roll-call voting, and policy adoption (e.g., Bernardi et al., 2020; Erikson et al., 1993; Hager \& Hilbig, 2020; Luna \& Zechmeister, 2005). For example, through a review of existing studies in multiparty elections, Adams et al. (2004) find that parties shift their policy positions to reflect voter preferences. In a cross-sectional analysis of 15 countries, Ezrow et al. (2011) further detail the relationship between voters' preferences and policymaking, showing that mainstream parties' policy positions are responsive to the preferences of the mean voter-while more "niche" parties are more responsive to the preferences of their own supporters. In alignment with these results, Lax and Phillips $(2012,2009)$ assessments of policy congruence across US states show that the relationship also applies subnationally: Citizens' opinions towards specific policies in a number of areas are closely associated with their state-level adoption.

As previously discussed, although the relationship between political ideology and attitudes towards women's rights in general, and VAW in particular, may be ambiguous, conservative voters may still share core values about the preservation of family units, government spending, and issue salience that may impact their overall preferences towards anti-VAW policy frameworks. Combining insights from the literatures on gender and politics, policymaking, and elite-mass congruence, we expect conservatism to shape voters' attitudes towards VAW and explain variation in the uptake of antiVAW policy instruments across local constituencies. Formally, we hypothesize that:

- H1 (aggregate-level): Governments representing conservative electorates tend to adopt fewer anti-VAW policy instruments.

- H2 (individual-level): Conservative voters are less likely to support the adoption of policies to tackle VAW.

\section{The Case of Brazil}

Emphasizing the persisting prevalence of VAW globally, women's movements from around the world have worked to make combating VAW a top priority in the global policy agenda. Their efforts have been successful (Htun \& Weldon, 2012; Medie \& Walsh, 2019; Weldon, 2002a; Weldon et al., 2011). 
Particularly since the 1979 United Nations' Convention for the Elimination of All Forms of Discrimination Against Women (CEDAW) ${ }^{2}$, the Vienna Declaration from 1993, and the Beijing Declaration and Platform for Action from 1995, there has been a global effort to better understand the dynamics of gender-based violence and to identify targeted policy instruments to eradicate it (Macaulay, 2000).

Latin America has been responsive to this global trend: In 1994, all countries in the region adopted the Inter-American Convention on the Prevention, Punishment and Eradication of Violence against Women, which explicitly recognizes VAW as a human rights' violation (Deus \& Gonzalez, 2019). Latin American activists and scholars have also been at the forefront of debates on gender-based violence, modifying Russell's concept of femicide as "the killing of females by males because they are female" (Russell \& Harmes, 2001) to feminicide, thus approximating the term to the meaning of "genocide" and emphasizing that the homicides of women because they are women characterize the disappearance of a specific group (Lagarde, 2006). To date, 13 countries in the region have adopted comprehensive policies to tackle VAW and 18 countries typify femicide/feminicide as a specific crime (Deus \& Gonzalez, 2019).

Brazil's efforts to combat VAW have followed this regional (and global) trend. In 1985, São Paulo inaugurated the world's first Women's Police Station - a type of institution that is now present in at least 16 other countries (Córdova \& Kras, 2020, p. 776). In 2006, the country sanctioned Law 11.340, largely known as the Maria da Penha Law, a progressive anti-VAW law. In many ways, the policymaking processes that yielded anti-VAW policies in Brazil are characteristic of the broader patterns identified by the literature: In both instances, policy innovation was preceded by pressure from international organizations, regional institutions, demands from women's movements, and lobbying from domestic NGOs and feminist scholars (Macaulay, 2000; MacDowell Santos, 2010). The long process that ultimately led to the adoption of Law 11.340 is particularly illustrative of the important role of these factors: the Law's name is in homage to Maria da Penha Maia Fernandes, a survivor of intimate-partner violence and two murder attempts whose case was only reexamined in Brazil after pressures from the Organization of American States and the Inter-American Commission on Human Rights. The case also prompted regional institutions to pressure Brazil to adopt anti-VAW specific legislation-which only happened years later in 2006, when, with the election of the left-wing Worker's Party to the presidency, feminist movements gained a greater level of state influence (Friedman, 2009).

As a product of consultation between the government, activists, and representatives from international organizations, the Maria da Penha Law is robust. Notably, it explicitly identifies VAW as a human rights' violation. The 
law also recognizes that gender-based violence has particular characteristics, and that, as such, combating it requires a comprehensive framework of specialized institutions. In particular, the law identifies and recommends the adoption of a number of protection and justice instruments specifically targeted at combating VAW (Machado et al., 2016, p. 187). Among others, these instruments include Women's Police Stations, women's shelters, specialized courts, and well-being service centers ${ }^{3}$.

But Brazil is a federal system and Brazilian municipalities have substantial power over the adoption of policies and programs (Funk \& Philips, 2019)including those pertaining to gender equality and women's rights' protection (Funk et al., 2017; Macaulay, 2000) and crime prevention and security ${ }^{4}$. That is, while the Maria da Penha Law applies nationally, the decision of adopting the Law's recommended policy instruments has remained under the authority of municipalities. As a result, there is wide variation in policy uptake across the country. Fourteen years after the Maria da Penha Law was enacted, only $21 \%(N=1163)$ of Brazil's 5570 municipalities have adopted at least one of the instruments recommended to implement the law's mandate. Crucially, lack of local commitment to the implementation of policy instruments can render national legislation "dead letter" (Macaulay, 2000, p. 153).

In turn, voters' influence over policymaking may be particularly strong at the local level where voters' closer approximation to their representatives allows them to better allocate responsibility and where representatives may be more knowledgeable about the preferences of their constituents across a wider range of issues (Fisman \& Gatti, 2002). In addition to bearing strong constituent pressures, local-level policymakers have less visibility than their national counterparts and likely face less international and transnational pressures (Steunenberg, 1996; Souza, 2016). As a result, policymaking at the local level may be particularly prone to being shaped by voters' ideological preferences (Fording et al., 2007; Franceschet \& Piscopo, 2013).

Brazil offers an ideal case to test whether voters' ideology shapes antiVAW policy uptake at the local level. As Powell Jr. (2004) describes, one of the obstacles to examining whether electorates' preferences translate into equivalent policy adoption is that "a multidimensional preference configuration can yield almost any configuration of outcomes" (p. 291). Therefore, assessing the relationship between ideological tendencies and policy adoption requires a context where potential outcomes are limited to a set of options (i.e., where variation is possible, but policy configurations are restricted). The Brazilian case offers this condition, since the Maria da Penha Law recommends a finite set of policy instruments to be adopted for tackling VAW.

In addition, measuring political ideology cross-nationally may create inconsistencies, but within-country comparative studies tend to employ countryspecific measures of ideology and thus circumvent problems of conceptual cohesion (Beer, 2017). Nonetheless, an obstacle that arises in within-country 
studies is capturing variation in the ideological preferences of the electoratea problem that is particularly salient in analyses of subnational units. Recently, Power and Rodrigues-Silveira (2019) have used data on the electoral results of Brazilian municipal elections to develop a measure of constituencies' "electorally revealed conservatism." These data allow us to capture variation in the ideological preferences of subnational electorates.

We test our hypotheses with a two-stage empirical strategy. First, we examine the association between constituencies' ideological preferences and the adoption of policy instruments to tackle VAW in Brazilian municipalities (Study 1). Second, we investigate whether individuals' conservative preferences are associated with lower levels of support for legal protections for women (Study 2). This step allows us to rule out the possibility of ecological fallacy bias in our municipal-level estimates.

\section{Study I: Municipal-Level Analysis}

For our municipal-level analyses, we combine data from a number of sources. First, to derive our outcome variables, we employ data from the IBGE. As part of the 2018 Survey of Basic Municipal Information (Pesquisa de Informações Básicas Municipais), the IBGE collected data on the presence or absence of a set of policy instruments identified by the federal government to tackle VAW $(N=5570)^{5}$.

Using these data, we derive three count variables to measure variation in anti-VAW policy uptake. The first variable, All policies, ranges from 0 to 10 and corresponds to the total number (i.e., sum) of policy instruments adopted in each municipality. The variable has a mean of 0.656 . Our second and third dependent variables distinguish between the types of policies and, respectively, capture the total number of Protection and Justice instruments adopted in each municipality. The variable Protection ranges from 0 to 4 and has a mean of 0.426 and Justice ranges from 0 to 6 and has a mean of 0.230 . The construction of these variables is consistent with the methodology employed by Htun and Weldon (2012) and Meier and Funk (2017).

Table 1 provides details on each of these instruments and their frequencies across municipalities. Overall, 21\% $(N=1163)$ of Brazilian municipalities adopted at least one policy instrument to tackle VAW. While Protection policies are more prevalent - this type of policy instrument was implemented by $30 \%$ of municipalities - Justice instruments are not rare events in our sample: $12 \%$ of Brazilian municipalities have adopted one or more Justice instruments.

Figure 1 illustrates the territorial distribution of the variable All policies across Brazil. As shown, these policies are not concentrated in the wealthiest municipalities located in more developed areas of the country: $43 \%(N=505)$ of the municipalities that adopted at least one policy instrument are located in 
Table I. Policy instruments to tackle VAW.

\begin{tabular}{|c|c|c|c|}
\hline $\begin{array}{l}\text { Type of Policy } \\
\text { Instrument }\end{array}$ & Policy Instrument Description & $N$ & $\%$ \\
\hline Protection & Municipal Council on Women's Rights & 1313 & 23.58 \\
\hline Protection & Specialized Women's Service Center & 385 & 6.91 \\
\hline Protection & Women's Shelters & 134 & 2.41 \\
\hline Protection & Sexual Violence Care Services & 540 & 9.70 \\
\hline Justice & Women's Police Station & 460 & 8.26 \\
\hline Justice & Special Court for VAW & 250 & 4.49 \\
\hline Justice & Specialized Gender Prosecutor's Office & 188 & 3.38 \\
\hline Justice & $\begin{array}{l}\text { Special Center for Women's Rights' } \\
\text { Protection (Public Attorney) }\end{array}$ & 87 & 1.56 \\
\hline Justice & Maria da Penha Police Patrol & 182 & 3.27 \\
\hline \multirow[t]{12}{*}{ Justice } & Aggressor Accountability Service & 113 & 2.03 \\
\hline & $\begin{array}{l}\text { Frequency Distribution of Policy } \\
\text { Instruments }\end{array}$ & $\mathbf{N}$ & $\%$ \\
\hline & Municipalities with 0 protection instruments & 3901 & 70.06 \\
\hline & Municipalities with I protection instrument & $1 \mid 74$ & 21.08 \\
\hline & Municipalities with 2 protection instruments & 328 & 5.89 \\
\hline & Municipalities with 3 protection instruments & 119 & 2.14 \\
\hline & $\begin{array}{l}\text { Municipalities with more than } 3 \text { protection } \\
\text { instruments }\end{array}$ & 46 & 0.83 \\
\hline & Municipalities with 0 justice instruments & 4902 & 88.04 \\
\hline & Municipalities with I justice instrument & 349 & 6.27 \\
\hline & Municipalities with 2 justice instruments & 163 & 2.93 \\
\hline & Municipalities with 3 justice instruments & 71 & 1.28 \\
\hline & $\begin{array}{l}\text { Municipalities with more than } 3 \text { justice } \\
\text { instruments }\end{array}$ & 83 & 1.49 \\
\hline
\end{tabular}

Source: Elaborated by the authors based on IBGE, 2018. The unit of analysis is the municipality. VAW: Violence against women.

the North or Northeast, Brazil's poorest regions. The same pattern of dispersion is observed within Brazil's five regions, so we do not identify geographical clusters of policy distribution.

To capture voters' ideological preferences, our main explanatory variable, we employ a measure of electoral conservatism developed by Power and Rodrigues-Silveira (2019). To derive this measure, the authors first establish ideological scores for each party, a process that is based on legislators' placements of Brazilian parties' electoral and policy reputations ${ }^{6}$. Electorates' levels of ideological conservatism are then calculated as a product of the ideological scores of the parties for which they voted: Each party's ideological score is multiplied by the share of votes it obtained in the municipal legislative elections of $2016^{7}$. The higher the proportion of votes won by a party, the 


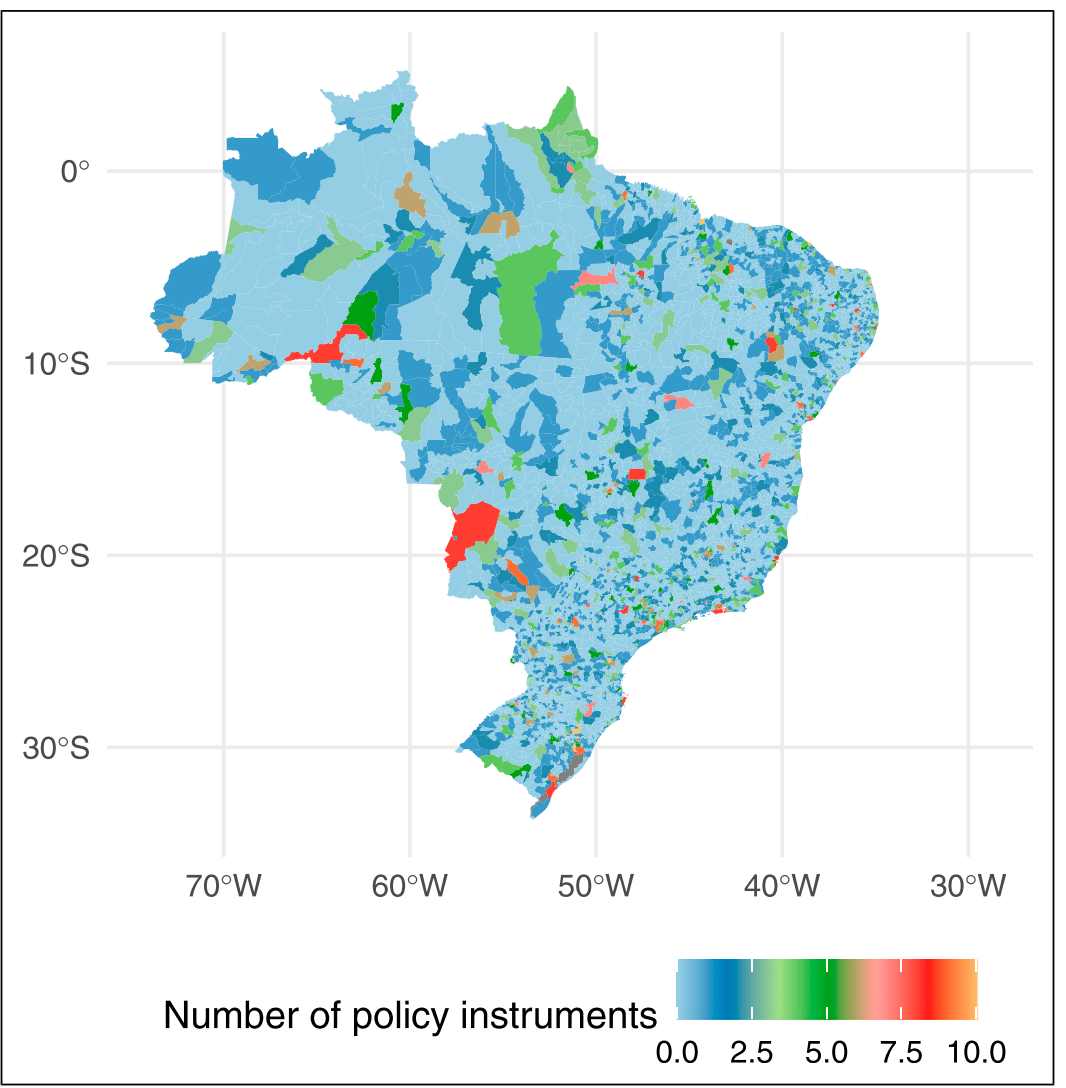

Figure I. Territorial distribution of policy instruments to tackle VAW in Brazil. Note: The unit of analysis is municipality $(N=5570)$.

higher its influence in shaping the final ideological score assigned to a given municipal constituency. More specifically, the measure was conceived in such as a way that -1 (negative 1) corresponds to extreme left ideology, 1 (positive 1) to extreme right ideology, and a value of 0 corresponds to centrist ideology: As Power and Rodrigues-Silveira (2019) describe, higher values on the scale indicate constituencies" "electorally revealed conservatism."

The adoption of police instruments to combat VAW could also be explained by socio-demographic factors ${ }^{8}$. First, it is possible that policy instruments are more likely to be adopted where VAW is particularly prevalent. We control for this with a measure of femicide rate, which we retrieve from the Mapa da Violência 2015 (Waiselfisz, 2015). Population demographics could also shape issue salience and policy demand (Lax \& Phillips, 2012). For example, it is possible that demand for policies to tackle VAW is higher where 
women represent a higher share of the population. In addition, social movements tend to be more active in more urban and highly populated areas (Uitermark et al., 2012). Previous work has shown that women's movements are crucial for policy adoption (Htun \& Weldon, 2012; Medie \& Walsh, 2019; Weldon, 2002a; Weldon et al., 2011), so it is also possible that policy demand varies depending on urbanization and population size. Accordingly, we employ data from the 2010 IBGE census to add controls for the share of women in the population (\% women population), the share of the population who live in urban areas (\% urban population), and population size (log) ${ }^{9}$. Existing scholarship has also shown that religiosity may impose obstacles to women's rights (Htun \& Weldon, 2011), so we include a control for the share of evangelicals in the population (\% evangelical $)^{10}$. Meanwhile, some literature conveys that inequality and socio-economic modernization may shape not only individuals' levels of vulnerability but also the government's propensity to adopt women-targeted policies (Inglehart \& Norris, 2003), so we also control for the level of human development (HDI).

It is also plausible that other political factors-besides electoral conservatism - shape policy uptake. First, municipalities with higher levels of bureaucratic capacity may be in a better position to adopt a greater number of policy instruments (Htun \& Weldon, 2010; Meier \& Funk, 2017) ${ }^{11}$. To capture this, we employ data from the IBGE's survey of municipalities to derive bureaucratic capacity, which measures the per capita number of employees in the public sector who completed tertiary education. It is also possible that it is not voters' ideology per se that reduces the prevalence of policies to tackle VAW in conservative municipalities, but that conservative voters are also less likely to elect women mayors and city councilors - and that, in turn, women are more likely to promote women's substantive representation (SchwindtBayer, 2010). To account for this, we use data from the Tribunal Superior Eleitoral (Superior Electoral Tribunal, TSE) to derive \% elected women (Mayor) and \% elected women (Council), which, respectively, measure the share of mayoral and city council offices that were occupied by women since the adoption of the Maria da Penha Law ${ }^{12}$. It is also possible that our results are not driven by electorates' ideological predispositions, but by the conservative leanings of elected officials. As such, we use TSE data and parties' ideological classifications established by Power and Rodrigues-Silveira (2019) to derive measures of \% elected conservative (Mayor) and \% elected conservative (Council) ${ }^{13}$. Finally, the existing literature has identified religious influence within the state as a source of rivalry to progressive protective policies for women (O'Brien \& Walsh, 2020). To control for this, we follow Boas (2014) and use data from the TSE to identify city councilors whose candidate (i.e., ballot) names included the title of "pastor" and derive the measure \% elected evangelical (Council) ${ }^{14}$. 
Formally, we run ordinary least squares models (OLS) as described by the following general equation

$$
Y_{i}=\beta_{0}+x_{i} \beta+W_{i}+e_{i}
$$

where $Y_{i}$ is the number of policy instruments to tackle VAW, $x_{i}$ is our main regressor that refers to the electoral conservatism indicator aforementioned, and $\mathrm{W}_{i}$ is a set of covariates potentially correlated with our dependent variable. The subscript ${ }_{i}$ indicates that the measures we include in the model vary across municipalities. We cluster standard errors at the municipal level, so $e_{i}$ captures unobservable municipal-level characteristics. Supplementary Material Appendix A shows the descriptive statistics for all municipal-level variables included in our estimates.

\section{Results}

To test H1, we examine whether levels of electoral conservatism impact the adoption of policy instruments to tackle VAW in Brazilian municipalities, as measured by our three dependent variables: All policies, Protection policies, and Justice policies. Table 2 summarizes our results.

In estimating the correlation between constituencies' levels of electoral conservatism and the prevalence of all municipal-level policy instruments when we control only for socio-demographic factors (model 1), we find that conservative ideology is negatively associated with the number of policy instruments adopted in a given municipality. More specifically, a one-point increase on the scale of electoral conservatism (where higher values correspond to more conservative preferences) is associated with an average of 0.45 fewer policy instruments at the municipal level. In other words, more conservative constituencies tend to adopt fewer policies to tackle VAW. Similarly, models 4 and 7 , which delimit the types of policy instruments to those pertaining to protection and justice (respectively), also produce negative and statistically significant coefficients.

Figure 2 graphically depicts our estimates for our full models 3, 6, and 9. As shown, the predicted number of policy instruments is higher under lower levels of conservatism even when we control for political factors. Our findings are not driven by a particular type of policy. Nonetheless, as illustrated, the impact of electoral conservatism on policy uptake is stronger in our models of Protection policies. This is aligned with previous work that suggests that although combating VAW may be a non-dogmatic policy area, preferences on how to combat VAW diverge (Neumann, 2018; O'Brien \& Walsh, 2020).

Importantly, the negative association between electoral conservatism and the adoption of policy instruments persists across all of our estimates, even in baseline models (Supplementary Material Appendix B) and models with 


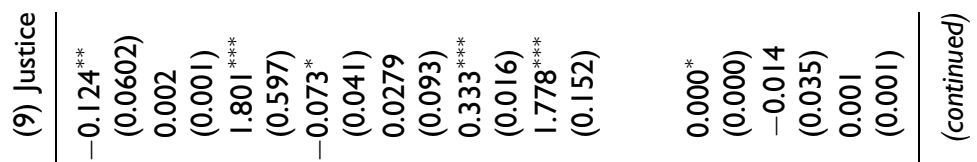

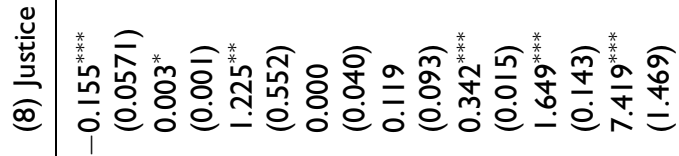

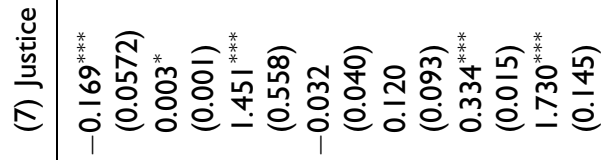

흠

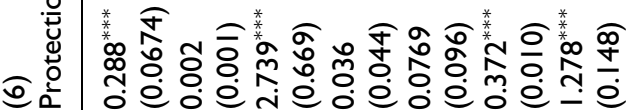

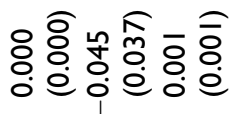

․ㅡㅇ

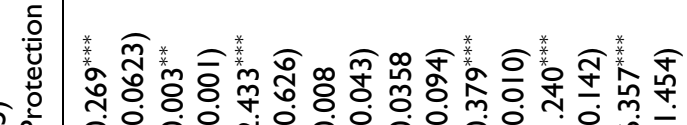

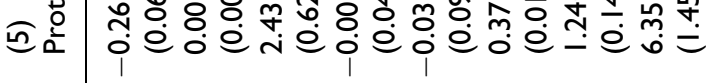

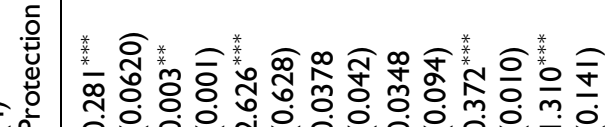

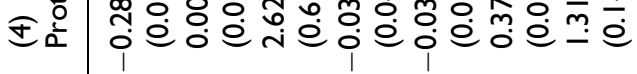

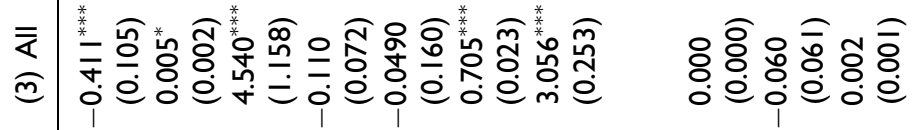

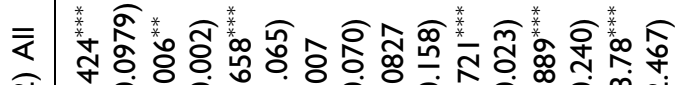

ح

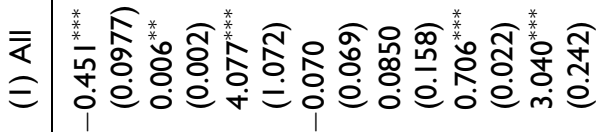




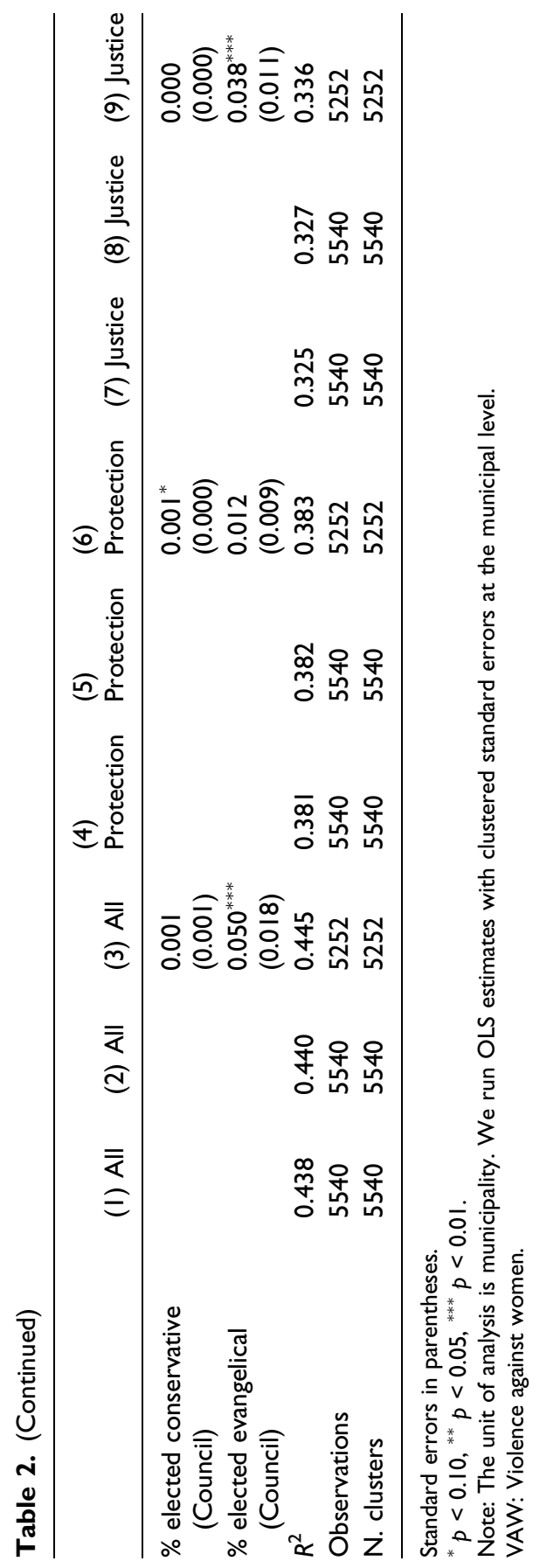




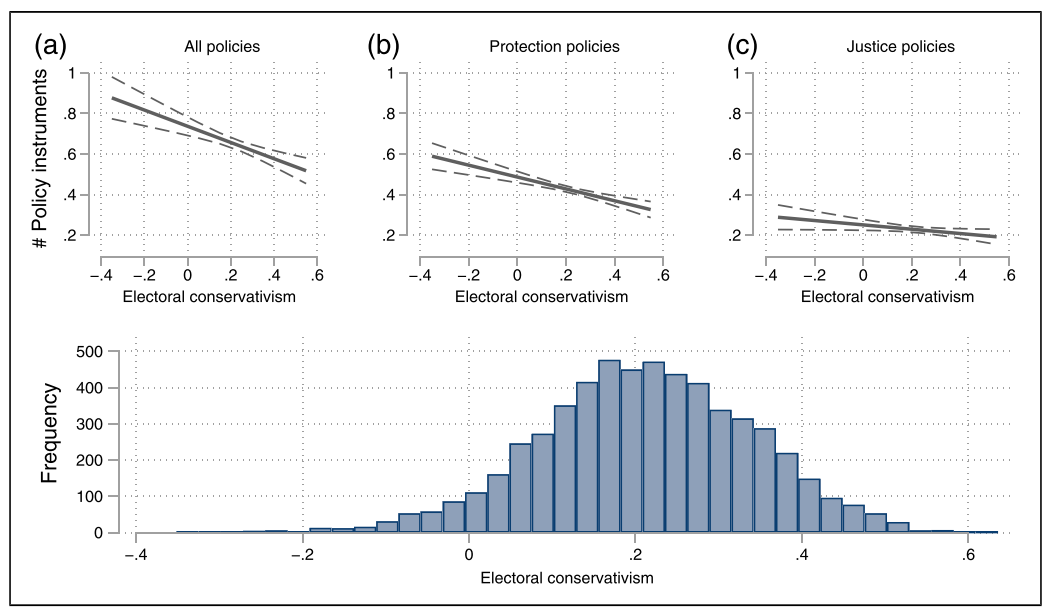

Figure 2. Predicted number of VAW policy instruments by constituencies' electoral conservatism.

Note: Panels A, B, and C illustrate results from models 3, 6, and 9 reported in Table 2, respectively. The unit of analysis is the municipality. OLS estimates with clustered standard errors at the municipal level.

controls for socio-economic and political factors potentially associated with policy adoption. Notably, the adoption of policy instruments is not a response to the prevalence of VAW: While femicide rate produces statistically significant coefficients across many of our models, the substantive impact of the variable is very small. As anticipated, a higher share of women in the population increases policy uptake - a result that is consistent throughout all models. Population size and levels of human development also increase municipalities' policy uptake. Although we cannot offer a more direct measure of the impact of women's movements at the municipal level, these results suggest the role of social pressures previously identified in other studies could also be at play here. Conversely, controls for urban and evangelical populations largely produce statistically insignificant estimates.

In addition, we find that only two of our six controls for different political factors consistently produce statistically significant coefficients. Bureaucratic capacity is strongly and positively associated with policy uptake. This means that municipalities with a more qualified public sector are also more likely to tackle VAW. Surprisingly, the greater presence of evangelical pastors in City Councils increases the uptake of policy provisions, a result that seems to be driven by justice provisions. One possible explanation is the Evangelical Caucus's close alignment to the Bullet Caucus at the national level, and, 
overall, to a punitive policy agenda (Cowan, 2016) ${ }^{15}$. Future studies could explore this relationship more in depth.

In contrast, we find no evidence to suggest that the effect of conservatism on policy instruments is a consequence of a lower presence of women mayors and/or councilors in conservative municipalities, or even of the greater presence of conservative mayors and/or councilors - as indicated by the lack of statistical significance of these controls in all of our models. These results suggest that voters' ideological preferences are more significant in shaping policy uptake than politicians' ideology - a result that resonates with findings from the existing literature that also do not find politicians' ideology to be a predictor of anti-VAW legislation (Beer, 2017; Htun \& Weldon, 2012). In other words, conservative electorates seem to be able to curb the adoption of policies to tackle VAW even when politicians are more progressive than the average voter.

Although electoral conservatism negatively impacts the uptake of both types of policy instruments, its impact on protection policies is more pronounced. As anticipated by H1, this suggests that conservative voters have distinct preferences towards anti-VAW policies and that these attitudes are reflected in public policy. Crucially, these instruments include Municipal Councils on Women's Rights, Women's Service Centers, and Women's Shelters - services meant to ensure the immediate safety of women and their dependents, to promote their well-being in the medium and long terms, and to decrease the chances of re-victimization (Machado et al., 2016; Senado, 2012; Tavares et al., 2019).

However, it is also possible that electoral conservatism impacts policy adoption not because of voters' attitudes towards VAW, but because of their preferences for small government. To explore this, we employ data from the 2018 Survey of Basic Municipal Information to derive outcome variables that measure policy uptake in a number of different areas, namely: Employment, income, credit, urban development, and rural development. As shown in Supplementary Material Appendix C, electoral conservatism does not seem to impact policy uptake in any of these areas.

In sum, the lower uptake of anti-VAW policy instruments in electorally conservative municipalities indeed seems to be a product of voters' preferences in this particular policy area. Our findings are aligned with theoretical (and normative) expectations of the functioning of representative democracies - but reinforce concerns about what the growth of conservative ideologies across global democracies may mean for women's rights. To provide further support for our claim that our municipal-level results are a product of elite-mass congruence, in the next section we explore conservative voters' attitudes towards VAW using individual-level data. 


\section{Study 2: Individual-Level Analysis}

As previous research has noted, one of the challenges of studying policy responsiveness is the lack of available metrics of citizens' policy opinions (Lax and Phillips, 2009, 2012). In other words, it could be that conservative voters may not hold preferences that would justify the less frequent adoption of instruments to tackle VAW in conservative constituencies. We address this by conducting a second study to explore individuals' attitudes and policy preferences towards $\mathrm{VAW}^{16}$.

For our individual-level analyses, we employ data from a nationally representative public opinion survey conducted on 02 and April 03, 2019, by DataFolha with 2086 Brazilian respondents over 16 years of age ${ }^{17}$. The sample includes respondents from 130 municipalities and has a margin of error of 2 percentage points.

To capture individual-level attitudes towards VAW and the need for policies to tackle it, we employ respondents' level of agreement with the following three statements:

- "Existing laws in Brazil are adequate to protect women."

- "In the last year, violence against women in Brazil increased."

- "Media exaggerates in their coverage of cases of violence against women."

From the answers to each statement, we produce three outcome variables: Law, Violence, and Media. To code each variable, we transform Likert-scale responses into binary measures, where a value of 1 corresponds to "completely agree" and all other answers take a value of 0 . This strategy is advisable because it allows us to differentiate between respondents who have strong attitudes towards VAW and those whose attitudes are less firm, thereby mitigating potential measurement errors caused by social desirability bias (Krumpal, 2013; Tourangeau \& Yan, 2007). The variable Law has a mean of 0.261 , Violence has a mean of 0.822 , and Media has a mean of 0.259 . Although we consider this classification as the most conservative, we also run robustness checks using alternative operationalizations.

The survey questionnaire does not contain measures of respondents' conservative tendencies, as traditionally measured by self-placement on a leftright ideological scale. In any case, as previous studies have shown, while leftright ideology scales may be useful to characterize political actors such as parties and legislators, the average respondent cannot reliably place their ideological preferences on such a scale (Ferrer \& Velasco, 2013). In the context of Brazil's highly fragmented party systems where the electorate bears weak partisan ties with any single party (Samuels \& Zucco, 2018), it is also not possible to use partisanship as a proxy for conservatism ${ }^{18}$. To more 
appropriately capture respondents' adherence to conservatism, we derive a measure of revealed conservative attitudes by combining respondents' answers to the following questions and statements:

- "Are you for or against Brazil receiving refugees from Venezuela?"

- "The more people that are incarcerated, the more safe is society."

- "I am a feminist/support feminism ${ }^{19}$."

To operationalize our measure of conservatism, we transform each question's scale into binary variables, where a value of 1 corresponds to more conservative preferences: Opposition to Venezuelan refugees; agreement that higher incarceration is associated with greater levels of safety; and antifeminism. We then calculate the sum of individuals' answers to all three questions and derive conservative (index). This measure varies between 0 and 3 , where 0 means the absence of conservatism and 3 means the maximum level of conservatism across these three items. This index has a mean of 0.830 . We also run our estimates using conservative (dummy), which takes a value of 1 if an individual scores 1 in at least one of our measures of conservatism described above and a value of 0 otherwise.

Since policy preferences may be shaped by other individual-level characteristics, we also include in our estimates controls for respondents' gender (with the variable woman), race (with the variable Black), age, schooling, income, evangelical, PT voter ${ }^{20}$, and municipality size.

Formally, we run logit estimates as described by the following general equation

$$
Y_{i}=\beta_{0}+x_{i} \beta+W_{i}+e_{i}
$$

where $\mathrm{Y}_{i}$ captures the attitudes towards VAW at the individual level, $\mathrm{X}_{i}$ is our main regressor that refers to the conservatism index, and $\mathrm{W}_{i}$ is a matrix of covariates that accounts for the characteristics of individuals included in our sample. $\mathrm{e}_{i}$ captures unobservable individual-level characteristics. We run the logit estimates as specified in equation (2) with clustered standard errors at the individual level. Supplementary Material Appendix D shows the descriptive statistics for all individual-level variables included in our estimates.

\section{Results}

To test $\mathrm{H} 2$, we first employ logit models to examine the effect of our measure of revealed conservatism on individuals' attitudes towards VAW. Following our expectations, as shown in Table 3, individuals who score higher values on our measure of conservatism are more likely to agree with the statement that "existing laws in Brazil are adequate to protect women." In other words, 
Table 3. The effect of conservatism (index) on attitudes towards VAW.

\begin{tabular}{lccc}
\hline & $(\mathrm{I})$ Law & $(2)$ Violence & $(3)$ Media \\
\hline Conservatism (index) & $0.337^{* * *}$ & -0.043 & $0.288^{* * *}$ \\
Woman & $(0.064)$ & $(0.076)$ & $(0.064)$ \\
& $-0.432^{* * *}$ & $0.500^{* * *}$ & $-0.544^{* * *}$ \\
Black & $(0.110)$ & $(0.125)$ & $(0.107)$ \\
& 0.066 & $0.326^{*}$ & 0.246 \\
Age & $(0.155)$ & $(0.195)$ & $(0.150)$ \\
& $0.005^{*}$ & 0.000 & $0.012^{* * *}$ \\
Schooling & $(0.003)$ & $(0.004)$ & $(0.003)$ \\
& $-0.212^{* * *}$ & $0.0696^{*}$ & -0.0226 \\
Income & $(0.034)$ & $(0.037)$ & $(0.032)$ \\
& -0.002 & $-0.156^{* * *}$ & $-0.107^{* *}$ \\
Evangelical & $(0.053)$ & $(0.056)$ & $(0.051)$ \\
& 0.087 & -0.069 & 0.024 \\
PT voter & $(0.114)$ & $(0.128)$ & $(0.113)$ \\
& 0.163 & 0.226 & -0.0656 \\
Municipality size & $(0.141)$ & $(0.175)$ & $(0.144)$ \\
Pseudo $R^{2}$ & $-0.065^{*}$ & $0.145^{* * *}$ & $-0.072^{* *}$ \\
Wald chi2 & $(0.035)$ & $(0.038)$ & $(0.033)$ \\
Observations & 0.063 & 0.029 & 0.036 \\
$N$. clusters & 129.5685 & 49.13996 & 82.5085 \\
& 1949 & 1930 & 1932 \\
Sand & 1949 & 1930 & 1932 \\
\hline
\end{tabular}

Standard errors in parentheses.

${ }^{*} p<0.10,{ }^{* *} p<0.05,{ }^{* * *} p<0.01$.

Note: The unit of analysis is individual respondents. We run logit estimates with clustered standard errors at the individual level.

VAW: Violence against women.

conservative voters are less likely than others to see the need for the adoption of new policies to tackle VAW.

Additionally, our results indicate that while conservatives are no different from progressives in their assessment of whether VAW increased (model 2), they are considerably more likely to believe that the "media exaggerates in their coverage of cases of violence against women" (model 3). Figure 3 presents our individual-level results in a more intuitive way. As shown, as conservatism increases ( $X$-axis), so does the predicted probability of agreeing that existing laws in Brazil are sufficiently adequate to protect woman from violence (Panel A), and that media coverage overestimates VAW (Panel C). This is consistent with the literature on policymaking, which argues that the identification of something as an urgency is crucial for their prioritization in the policy agenda (Jones \& Baumgartner, 2005). Notably, our estimates are 


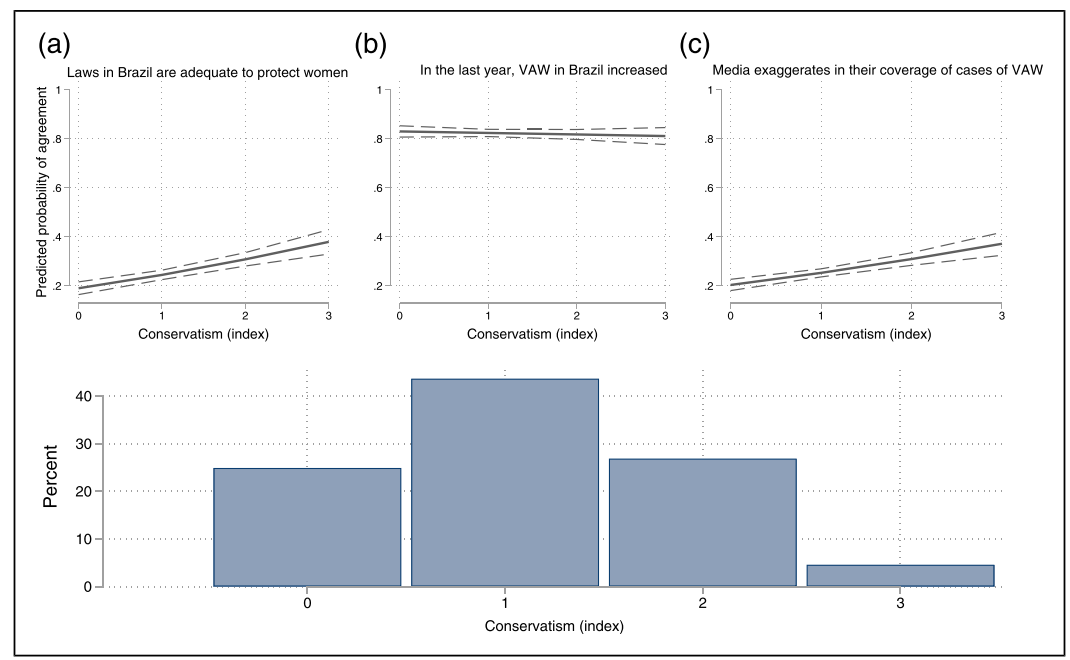

Figure 3. Predicted probability of individuals' agreement with statements concerning VAW, by levels of conservatism.

Note: Panels A, B, and C illustrate results from models I, 2, and 3 reported in Table 3, respectively. The unit of analysis is individual respondent. Logit estimates with clustered standard errors at the individual level. VAW: Violence against women.

not sensitive to alternative operationalizations or model specifications: Our results are robust in baseline models (Supplementary Material Appendix E); when we take two alternative approaches to collapsing Likert-scale responses to measure our dependent variables (Supplementary Material Appendix F); when we measure conservatism with a binary variable (Supplementary Material Appendix G); and when we run our models with municipal-level fixed effects to account for variation in policy frameworks across municipalities where respondents live (Supplementary Material Appendix H).

The statistically significant coefficients produced by our measure of conservatism are not the only ones that stand out: As our results in Table 3 indicate, respondents' gender is also an important and consistent predictor of attitudes towards VAW. On average, women are more likely than men to believe that existing laws are insufficient to tackle VAW; to agree that there has been an increase in VAW in the last year; and to disagree that the media exaggerates in their coverage of VAW. This is not surprising. Previous work applied to other contexts has also found gender gaps in policy preferences (e.g., Gottlieb et al., 2018), particularly those pertaining to gender equality (e.g., Taylor-Robinson \& Heath, 2003). Black respondents are also more likely to agree that VAW increased in the last year. It makes sense that the persistence of VAW is more prominently identified by Black respondents. As previous studies show, VAW in Brazil is racialized and Black women are more 
likely than white women to be victims of femicide (Ferraz \& Schiavon, 2019). In addition, formal educational attainment is also associated with higher levels of agreement that existing laws are insufficient to tackle VAW and that VAW increased in the last year-but has no effect on perceptions of whether the media exaggerates on their coverage of VAW. Finally, our results also indicate that respondents from larger municipalities are more likely to agree that existing laws are insufficient to tackle VAW, that VAW has increased, and that media coverage is not exaggerated.

Overall, the results of our individual-level analyses reinforce our municipal-level findings and suggest that, indeed, the lower prevalence of instruments to combat VAW in more electorally conservative municipalities is a product of conservative voters' lower levels of support for the need for these policies and recognition of VAW as an urgency. These findings indicate that our municipal-level results are not the product of an ecological fallacy: Conservative voters perceive the prevalence of VAW as exaggerated and do not prioritize tackling VAW on the policy agenda.

\section{Conclusion}

The relationship between ideology and women's rights has always been an interest to scholars. While in the past, conservative actors may have been more likely to openly display anti-women's rights attitudes and policy preferences, this relationship has become more ambiguous in recent years, as conservative parties and politicians increasingly incorporate women's rights into their agendas (O'Brien, 2018). Notably, the relationship between ideology and the adoption of policies to tackle VAW, a non-dogmatic issue, has been particularly weak. That is, previous work has largely found that governments' dominant ideology does not shape their likelihood of adopting anti-VAW legislation (Beer, 2017; Htun \& Weldon, 2012).

Alarmed by the rapid rise of conservative forces around the world, however, concerns about the threat of conservatism on women's rights have been reignited (Biroli \& Caminotti, 2020; Kováts, 2018; Payne \& de Souza Santos, 2020). In assessing the impact of ideology on women's rights, most existing research has focused on the role of politicians and parties in influencing policy. As of yet, we do not know much about the role of electoral conservatism on policymaking. Nonetheless, as the literature on elite-mass congruence shows, voters can meaningfully influence policy outputs (Lax \& Phillips, 2012). This raises the question: Can electoral conservatism make women more vulnerable to violence?

We take a two-step approach to answering this question. First, we examine whether levels of electoral conservatism in the electorate are associated with the adoption of anti-VAW policy instruments. For this, we employ municipallevel data from 5570 Brazilian municipalities and find, consistently with $\mathrm{H}$, 
that municipalities with more conservative electorates adopt fewer policy instruments to tackle VAW. Conservative electorates are particularly detrimental to the adoption of protection instruments, which are key to ascertain the safety of women and their dependents in the short term, and their wellbeing in the long term (Machado et al., 2016; Senado, 2012; Tavares et al., 2019). In addition, our analyses suggest that the negative impact of conservative electorates on policy uptake also does not seem to result from conservative voters' attitudes towards government spending, but from their non-prioritization of VAW: Employing survey data from a nationally representative sample of Brazilian respondents to test the association between conservatism and attitudes towards VAW, we find that, as per $\mathrm{H} 2$, conservative individuals are indeed less likely to see the need for additional policies to protect women from violence.

Together, the results from our municipal- and individual-level analyses suggest that, as normatively expected by the "pact" of representative democracies, electorates' ideological preferences shape public policy on the ground. When the electorate holds conservative preferences, however, policy congruence may impose costs to women's rights. These findings raise a number of questions for further research.

First, while we find electoral conservatism to be a key factor explaining policy adoption, it is unlikely that individual voters' preferences all have the same weight in influencing public policy; as such, future work may want to further inquire about whose conservatisms are politicians most responsive to. Second, evangelical voters and political figures are increasingly gaining influence in Latin America and beyond. Their attitudes towards VAW and role in shaping anti-VAW policy deserve further attention. More broadly, our findings contribute to ongoing debates about the potential impact of the rise of conservatism on women's rights around the world. Similarly to Brazil, other countries-including Argentina, France, Germany, India, Mexico, Poland, Switzerland, and the United States-also provide contexts where local governments can have high levels of discretion over policymaking (Ladner et al., 2016) and where the rise of conservatism in the electorate could translate into heterogeneous subnational protections for women.

\section{Acknowledgments}

Authors' names are listed in alphabetical order. We are thankful to Daniel Bischof, Mariana Carvalho, Kendall Funk, Fabrizio Gilardi, Patrícia Nabuco, Timothy J. Power, and Debora Thomé for their helpful comments and suggestions. All remaining errors are our entire responsibility. 


\section{Declaration of Conflicting Interests}

The author(s) declared no potential conflicts of interest with respect to the research, authorship, and/or publication of this article.

\section{Funding}

The author(s) received no financial support for the research, authorship, and/or publication of this article.

\section{ORCID iDs}

Victor Araújo (D) https://orcid.org/0000-0001-5392-5646

Malu A. C. Gatto (D) https://orcid.org/0000-0003-4056-5770

\section{Supplemental Material}

Supplemental material for this article is available online.

\section{Notes}

1. As Weldon (2002b) discusses, the same, of course, applies to the concepts of "progressive" or "left-wing" (p. 22).

2. As Baldez (2011) notes, VAW is not explicitly mentioned in CEDAW's articles, but in 1992 the CEDAW Committee made tackling VAW a central aspect of their approach to reducing gender-based discrimination (p. 422).

3. For a full list of instruments, see Table 1. For a description of these instruments, see: https://www12.senado.leg.br/institucional/omv/acoes-contra-violencia/servicosespecializados-de-atendimento-a-mulher.

4. As Peres et al. (2014) convey, since the early 2000s, Brazilian municipalities have become increasingly involved in the development and implementation of policy on public security. For example, while constitutionally the decision of instituting police stations lies with state governments, municipalities are often the ones financing the operating costs of these stations, including paying for buildings, vehicles, and other infrastructure. This also extends to Women's Police Stations, which are more often adopted as the product of negotiations between state and municipal governments, and which rely on funding and administration from municipal authorities (Pasinato et al., 2008, p. 13).

5. Replication materials and code can be found at Araújo and Gatto (2021).

6. Legislators' scores of their own parties are discounted, as the authors detail.

7. These data are only available for 2016 but, as Power and Zucco (2012) show, conservative preferences of the Brazilian electorate have become increasingly stable (p. 6).

8. Socio-demographic factors tend to change slowly (Inglehart \& Norris, 2003), so we employ the most recent available data. 
9. Population size may also be capturing other dynamics. For example, smaller municipalities may be more conservative than urban centers (Power \& RodriguesSilveira, 2019, p. 13). In addition, while municipality size is not a criterion of for the adoption of anti-VAW policy instruments, some instruments, such as women's police stations, are more likely to be present in larger municipalities (Córdova \& Kras, 2020, p. 785).

10. As Vaggione and Machado (2020) and Machado et al. (2018) show, evangelicals in Latin American are particularly more likely (than Catholics, for example) to emphasize moral issues in the political and policy arenas.

11. Other political factors, such as policy centralization and national women's agencies, may also impact policy uptake (Franceschet, 2010; Franceschet \& Piscopo, 2013). In our within-country analysis, these factors are held constant.

12. The 2018 Survey of Basic Municipal Information does not provide information about the year in which a given municipality adopted each policy instrument, so we account for those in office in the period since the adoption of the national Maria da Penha Law in 2006. This encompasses mayors and city councilors elected between 2004 and 2016.

13. As before, this encompasses mayors and city councilors elected between 2004 and 2016.

14. This encompasses city councilors elected between 2004 and 2016. Elected mayors whose ballot names include the title of "pastor" are rare events, so we do not employ this variable.

15. The Maria da Penha Law explicitly prohibits the use of decriminalizing measures that could favor the maintenance of family units, such as reconciliation and mediation (MacDowell Santos, 2010). This protocol has to be applied by all judicial institutions and actors in Brazil, whether or not they are specialized (Pasinato, 2015). Thus, and perhaps unlike other systems, the adoption of judicial instruments in the Brazilian case does not increase the employment of "antifamily" practices.

16. To be clear, while our data allow for the assessment of public opinion on a specific policy area, they do not allow us to make claims about voters' preferences in specific subnational units (Lax \& Phillips, 2012). This means that our individuallevel analyses do not directly map onto our municipal-level results.

17. In Brazil, voting is compulsory for citizens between the ages of 18 and 70 and optional from the ages of 16 and above 70.

18. With the exception of the center-left Partido dos Trabalhadores (Worker's Party, PT), for which we add a control, as explained.

19. In the survey questionnaire, women were asked about whether they identify as feminists, while men were asked if they support feminism. We combine women's and men's answers to create a single variable applicable to all.

20. As many studies have shown, among Brazil's 35 registered parties the PT is the only one that has been able to attain and maintain mass partisanship (Samuels \& Zucco, 2018). 


\section{References}

Adams, J., Clark, M., Ezrow, L., \& Glasgow, G. (2004). Understanding change and stability in party ideologies: Do parties respond to public opinion or to past election results? British Journal of Political Science, 34(4), 589-610.

Adsera, A., Boix, C., \& Payne, M. (2003). Are you being served? Political accountability and quality of government. The Journal of Law, Economics, and Organization, 19(2), 445-490.

Akkerman, T. (2015). Gender and the radical right in western Europe: A comparative analysis of policy agendas. Patterns of Prejudice, 49(1-2), 37-60.

Araújo, V., \& Gatto, M. A. C. (2021). Replication data for: Can conservatism make women more vulnerable to violence? DOI: 10.7910/DVN/YL8V4Y.

Baldez, L. (2011). The UN convention to eliminate all forms of discrimination against women (cedaw): A new way to measure women's interests. Politics \& Gender, 7(3), 419-423.

Beckwith, K. (2000). Beyond compare? Women's movements in comparative perspective. European Journal of Political Research, 37(4), 431-468.

Beckwith, K., \& Cowell-Meyers, K. (2007). Sheer numbers: Critical representation thresholds and women's political representation. Perspectives on Politics, 5(3), 553-565.

Beer, C. (2017). Left parties and violence against women legislation in Mexico. Social Politics: International Studies in Gender, State \& Society, 24(4), 511-537.

Beer, C. (2019). Multilevel causation in gender policy: Abortion and violence against women laws in the Mexican states. In A. Giraudy, E. Moncada, \& R. Snyder (Eds.), Inside countries: Subnational research in comparative politics. Cambridge University Press.

Bentancur, V. P., \& Rocha-Carpiuc, C. (2020). The postreform stage: Understanding backlash against sexual policies in Latin America. Politics \& Gender, 16(1), E3.

Bernardi, L., Bischof, D., \& Wouters, R. (2020). The public, the protester, and the bill: Do legislative agendas respond to public opinion signals? Journal of European Public Policy, 28(2), 1-22.

Biroli, F., \& Caminotti, M. (2020). The conservative backlash against gender in Latin America. Politics \& Gender, 16(1), E1.

Blofield, M., Ewig, C., \& Piscopo, J. M. (2017). The reactive left: Gender equality and the Latin American pink tide. Social Politics, 24(4), 345-369.

Boas, T. C. (2014). Pastor Paulo vs. Doctor Carlos: Professional titles as voting heuristics in Brazil. Journal of Politics in Latin America, 6(2), 39-72.

Bryson, V., \& Heppell, T. (2010). Conservatism and feminism: The case of the British conservative party. Journal of Political Ideologies, 15(1), 31-50.

Caul, M. (2001). Political parties and the adoption of candidate gender quotas: A crossnational analysis. Journal of Politics, 63(4), 1214-1229.

Celis, K., \& Childs, S. (2012). The substantive representation of women: What to do with conservative claims? Political Studies, 60(1), 213-225. 
Celis, K., \& Childs, S. (2018). Conservatism and women's political representation. Politics \& Gender, 14(1), 5-26.

Celis, K., \& Erzeel, S. (2015). Beyond the usual suspects: Non-left, male and nonfeminist MPs and the substantive representation of women. Government and Opposition, 50(1), 45-64.

Cerqueira, D. R. d. C., Bueno, S., Lima, R. S. d., Neme, C., Helder, F., Paloma Palmieri, A., David, M., Reis, M., Cypriano, O., Sobral, I., et al. (2019). Atlas da violência 2019. Technical report. Instituto de Pesquisa Econômica Aplicada (IPEA).

Childs, S., Webb, P., \& Marthaler, S. (2010). Constituting and substantively representing women: Applying new approaches to a UK case study. Politics \& Gender, 6(2), 199-223.

Córdova, A., \& Kras, H. (2020). Addressing violence against women: The effect of women's police stations on police legitimacy. Comparative Political Studies, 53(5), 775-808.

Cowan, B. A. (2016). Holy ghosts of Brazil's past: The reactionary "bullets, beef, and bibles" caucus in Brazil's national legislature reveals what is new, and not-so-new, about Brazil's new right. NACLA Report on the Americas, 48(4), 346-352.

Dahl, R. A. (1989). Democracy and its critics. Yale University Press.

Deus, A., \& Gonzalez, D. (2019). Analysis of femicide/feminicide legislation in Latin America and the Caribbean and a proposal for a model law. Technical report.

Erikson, R. S., Wright, G. C., Wright, G. C., \& McIver, J. P. (1993). Statehouse democracy: Public opinion and policy in the American states. Cambridge University Press.

Ezrow, L., De Vries, C., Steenbergen, M., \& Edwards, E. (2011). Mean voter representation and partisan constituency representation: Do parties respond to the mean voter position or to their supporters? Party Politics, 17(3), 275-301.

Ferraz, C., \& Schiavon, L. (2019). Breaking the cycle: The impact of legal reforms on domestic violence. Working Paper.

Ferrer, L. E. G., \& Velasco, R. Q. (2013). Izquierda y derecha: Formas de definirlas, el caso latinoamericano y sus implicaciones. América Latina Hoy, 65, 79-105.

Fisman, R., \& Gatti, R. (2002). Decentralization and corruption: Evidence across countries. Journal of Public Economics, 83(3), 325-345.

Fording, R. C., Soss, J., \& Schram, S. F. (2007). Devolution, discretion, and the effect of local political values on tanf sanctioning. Social Service Review, 81(2), 285-316.

Franceschet, S. (2010). Explaining domestic violence policy outcomes in Chile and Argentina. Latin American Politics and Society, 52(3), 1-29.

Franceschet, S., \& Piscopo, J. M. (2013). Federalism, decentralization, and reproductive rights in Argentina and Chile. Publius: The Journal of Federalism, 43(1), 129-150.

Friedman, E. J. (2009). Re(gion) alizing women's human rights in Latin America. Politics \& Gender, 5(3), 349-375. 
Funk, K. D., Hinojosa, M., \& Piscopo, J. M. (2017). Still left behind: Gender, political parties, and Latin America's pink tide. Social Politics: International Studies in Gender, State \& Society, 24(4), 399-424.

Funk, K. D., \& Philips, A. Q. (2019). Representative budgeting: Women mayors and the composition of spending in local governments. Political Research Quarterly, 72(1), 19-33.

García-Moreno, C., Pallitto, C., Devries, K., Stöck1, H., Watts, C., \& Abrahams, N. (2013). Global and regional estimates of violence against women: Prevalence and health effects of intimate partner violence and non-partner sexual violence. World Health Organization.

Gottlieb, J., Grossman, G., \& Robinson, A. L. (2018). Do men and women have different policy preferences in Africa? Determinants and implications of gender gaps in policy prioritization. British Journal of Political Science, 48(3), 611-636.

Hager, A., \& Hilbig, H. (2020). Does public opinion affect political speech? American Journal of Political Science, 64(4), 921-937.

Hayes, C. (2007). Tackling violence against women: A worldwide approach. In G. Terry \& J. Hoare (Eds.), Gender-based violence. Oxfam.

Htun, M., \& Piscopo, J. (2014). Women in politics and policy in Latin America and the Caribbean. In: Conflict prevention and peace forum CPPF working papers on women in politics (Vol. 2). Social Science Research Council.

Htun, M., \& Weldon, S. L. (2010). When do governments promote women's rights? A framework for the comparative analysis of sex equality policy. Perspectives on Politics, 8(1), 207-216.

Htun, M., \& Weldon, S. L. (2011). State power, religion, and women's rights: A comparative analysis of family law. Indiana Journal of Global Legal Studies, 18(1), 145-165.

Htun, M., \& Weldon, S. L. (2012). The civic origins of progressive policy change: Combating violence against women in global perspective, 1975-2005. American Political Science Review, 106(3), 548-569.

Huber, J. D., \& Powell, G. B. (1994). Congruence between citizens and policymakers in two visions of liberal democracy. World Politics, 46(3), 291-326.

Hughes, C., Marrs, C., \& Sweetman, C. (2016). Introduction to gender, development and VAWG. Gender \& Development, 24(2), 124-169.

Inglehart, R., \& Norris, P. (2003). Rising tide: Gender equality and cultural change around the world. Cambridge University Press.

Jones, B. D., \& Baumgartner, F. R. (2005). The politics of attention: How government prioritizes problems. University of Chicago Press.

Kováts, E. (2018). Questioning consensuses: Right-wing populism, anti-populism, and the threat of 'gender ideology'. Sociological Research Online, 23(2), 528-538.

Krumpal, I. (2013). Determinants of social desirability bias in sensitive surveys: A literature review. Quality \& Quantity, 47(4), 2025-2047.

Ladner, A., Keuffer, N., \& Baldersheim, H. (2016). Measuring local autonomy in 39 countries (1990-2014). Regional \& Federal Studies, 26(3), 321-357. 
Lagarde, M. (2006) Feminicidio: Una perspectiva global (Vol. 7). UNAM.

Lax, J. R., \& Phillips, J. H. (2009). Gay rights in the states: Public opinion and policy responsiveness. American Political Science Review, 103(3), 367-386.

Lax, J. R., \& Phillips, J. H. (2012). The democratic deficit in the states. American Journal of Political Science, 56(1), 148-166.

Lodders, V., \& Weldon, S. (2019). Why do women vote radical right? Benevolent sexism, representation and inclusion in four countries. Representation, 55(4), 457-474.

Luna, J. P., \& Kaltwasser, C. R. (2014). The resilience of the Latin American right. JHU Press.

Luna, J. P., \& Zechmeister, E. J. (2005). Political representation in Latin America: A study of elite-mass congruence in nine countries. Comparative Political Studies, $38(4), 388-416$.

Macaulay, F. (2000). Tackling violence against women in Brazil: Converting international principles into effective local policy. In D. S. Jacobs, R. Jacobsen, \& J. Marchbank (Eds.), States of conflict: Gender, violence and resistance. Palgrave Macmillan.

Macaulay, F. (2010). Trickling up, down, and sideways: Gender policy and political opportunity in Brazil. In N. Lebon \& E. Maier (Eds.), Women's activism in Latin America and the caribbean: Engendering social justice, democratizing citizenship. Rutgers University Press.

MacDowell Santos, C. (2010). Da delegacia da mulher à Lei Maria da Penha: Absorção/tradução de demandas feministas pelo estado. Revista Crítica de Ciências Sociais, 89, 153-170.

Machado, M. d. D. C., et al. (2018). Religion and moral conservatism in Brazilian politics. Politics and Religion Journal, 12(1), 55-74.

Machado, I. V., Lopes, A. G., Venâncio, K. E. A., Lessa, L. D. M., de Lima, M. A. P., \& Costa, M. F. (2016). Lei Maria da Penha: A importância das políticas públicas de abrigamento no contexto do enfrentamento às violências contra as mulheres. Revista Direitos Humanos e Democracia, 4(7), 172-199.

Mazur, A. G. (2002). Theorizing feminist policy. Oxford University Press.

Medie, P. A., \& Walsh, S. D. (2019). International organizations, nongovernmental organizations, and police implementation of domestic violence policies in Liberia and Nicaragua (pp. 1-31). Politics \& Gender.

Meier, K. J., \& Funk, K. D. (2017). Women and public administration in a comparative perspective: The case of representation in Brazilian local governments. Administration \& Society, 49(1), 121-142.

Neumann, P. J. (2018). Transnational governance, local politics, and gender violence law in Nicaragua. Latin American Politics and Society, 60(2), 61-82.

O'Brien, D. Z. (2018). "Righting" conventional wisdom: Women and right parties in established democracies. Politics \& Gender, 14(1), 27-55. 
O'Brien, C., \& Walsh, S. D. (2020). Women's rights and opposition: Explaining the stunted rise and sudden reversals of progressive violence against women policies in contentious contexts. Journal of Latin American Studies, 52(1), 107-131.

Page, B. I., \& Shapiro, R. Y. (1983). Effects of public opinion on policy (pp. 175-190). American Political Science Review.

Pasinato, W. (2015). Acesso à justiça e violência doméstica e familiar contra as mulheres: As percepções dos operadores jurídicos e os limites para a aplicação da Lei Maria da Penha. Revista Direito GV, 11(2), 407-428.

Pasinato, W., \& MacDowell Santos, C. (2008). Mapeamento das delegacias da mulher no Brasil. São PauloPAGU, UNICAMP.

Payne, L. A., \& de Souza Santos, A. A. (2020). The right-wing backlash in Brazil and beyond. Politics \& Gender, 16(1), E6.

Peres, U. D., Bueno, S., da Silva Leite, C. K., \& de Lima, R. S. (2014). Segurança pública: Reflexões sobre o financiamento de suas políticas públicas no contexto federativo brasileiro. Revista Brasileira de Segurança Pública, 8(1).

Powell, G. B. Jr (2004). Political representation in comparative politics. Annual Review of Political Science, 7, 273-296.

Power, T. J., \& Rodrigues-Silveira, R. (2019). Mapping ideological preferences in Brazilian elections, 1994-2018: A municipal-level study. Brazilian Political Science Review, 13(1).

Power, T. J., \& Zucco, C. Jr (2012). Elite preferences in a consolidating democracy: The Brazilian legislative surveys, 1990-2009. Latin American Politics and Society, 54(4), 1-27.

Przeworski, A., Stokes, S. C. S., Stokes, S. C., \& Manin, B. (1999) Democracy, accountability, and representation (Vol. 2). Cambridge University Press.

Russell, D. E., \& Harmes, R. A. (2001). Femicide in global perspective. Teachers College Press.

Samuels, D. J., \& Zucco, C. (2018). Partisans, antipartisans, and nonpartisans: Voting behavior in Brazil. Cambridge University Press.

Schwindt-Bayer, L. A. (2010). Political power and women's representation in Latin America. Oxford University Press.

Senado (2012). Boletim mulheres e seus temas emergentes. Technical report. Instituto de Pesquisa do Senado.

Souza, C. (2016). Constitutional engineering in Brazil: The politics of federalism and decentralization. Springer.

Steunenberg, B. (1996). Agent discretion, regulatory policymaking, and different institutional arrangements. Public Choice, 86(3-4), 309-339.

Tavares, P., Sangostino Recavarren, I., \& Sinha, A. (2019). Protecting women from violence: Bridging the implementation gap between law and practice. World Bank Research and Development Center.

Taylor-Robinson, M., \& Heath, R. M. (2003). Do women legislators have different policy priorities than their male colleagues? A critical case test. Women \& Politics, 24(4), 77-101. 
Tourangeau, R., \& Yan, T. (2007). Sensitive questions in surveys. Psychological Bulletin, 133(5), 859-883.

Uitermark, J., Nicholls, W., \& Loopmans, M. (2012). Cities and social movements: Theorizing beyond the right to the city.

Vaggione, J. M., \& Machado, M. D. D. C. (2020). Religious patterns of neoconservatism in Latin America. Politics \& Gender, 16(1), E2.

Waiselfisz, J. J. (2015). Mapa da violência 2015: Homicídio de mulheres no Brasil. Flacso Brasil.

Weldon, S. L. (2002a). Beyond bodies: Institutional sources of representation for women in democratic policymaking. The Journal of Politics, 64(4), 1153-1174.

Weldon, S. L. (2002b). Protest, policy, and the problem of violence against women: A cross-national comparison. University of Pittsburgh Press.

Weldon, L., et al. (2011). When protest makes policy: How social movements represent disadvantaged groups. University of Michigan Press.

World Bank, T (2020). Women, business and the law 2020. World Bank. https:// openknowledge.worldbank.org/handle/10986/32639. 